\title{
Enhancing the sense of self of a mid-career woman through career construction counselling
}

\author{
Jacobus G. Maree ${ }^{1} \mathbb{D} \cdot$ Mia Nortjé
}

Received: 29 July 2020 / Accepted: 30 December 2021

(c) The Author(s), under exclusive licence to Springer Nature B.V. 2022

\begin{abstract}
This article reports on career construction counselling with a purposefully selected, mid-career, midlife woman. A single-case study research design was implemented. Data were gathered using an integrative qualitative and quantitative approach. After the intervention, the participant exhibited an enhanced sense of self-awareness. Career construction counselling can be used to help a mid-career, midlife woman become more aware of the meaning she assigned to life and her view of herself. Future research with diverse mid-career, midlife women (individually or in groupbased settings) is needed to establish the effectiveness and long-term effects of the kind of intervention espoused here.
\end{abstract}

Keywords Career construction counselling · Career indecision · Intervention research

\section{Résumé}

Améliorer le sentiment de soi d'une femme à mi-carrière grâce à l'entretien de construction de carrière

Cet article présente les résultats d'un entretien de construction de carrière mené auprès d'une femme à mi-carrière et en milieu de vie, sélectionnée de manière ciblée. Une étude de cas unique a été mise en place. Les données ont été recueillies en utilisant une approche qualitative et quantitative intégrative. Après l'intervention, la participante a montré un sens accru de la conscience de soi. L'entretien de construction de carrière peut être utilisé pour aider une femme à mi-carrière et en milieu de vie à devenir plus consciente du sens qu'elle donne à sa vie et à sa vision d'ellemême. Des recherches futures avec diverses femmes à mi-carrière et en milieu de vie (individuellement ou en groupe) sont nécessaires pour établir l'efficacité et les effets à long terme de ce type d'intervention.

Jacobus G. Maree

kobus.maree@up.ac.za

Mia Nortjé

nortje.mia@gmail.com

1 Department of Educational Psychology, University of Pretoria, Pretoria, South Africa 


\section{Zusammenfassung}

Stärkung des Selbstbewusstseins einer Frau in der Mitte ihrer beruflichen Laufbahn durch eine Beratung gemäß der Career Construction Theorie

In diesem Artikel wird über eine Beratung gemäß der Career Construction Theorie mit einer gezielt ausgewählten Frau in der Mitte ihrer beruflichen Laufbahn und in der Lebensmitte berichtet. Es wurde ein Forschungsdesign mit einer Einzelfallstudie umgesetzt. Die Daten wurden mit einem integrativen qualitativen und quantitativen Ansatz erhoben. Nach der Intervention zeigte die Teilnehmerin eine verbesserte Selbstwahrnehmung. Die Beratung gemäß der Career Construction Theorie kann einer Frau in der Mitte ihrer Laufbahn und in der Lebensmitte dabei helfen, sich der Bedeutung, die sie ihrem Leben beimisst, und ihrer Sicht auf sich selbst bewusster zu werden. Zukünftige Forschungen mit verschiedenen Frauen in der Mitte ihrer Laufbahn und in der Lebensmitte (in Einzel- oder Gruppensettings) sind erforderlich, um die Wirksamkeit und die langfristigen Auswirkungen der hier vorgestellten Art von Intervention zu ermitteln.

\section{Resumen}

\section{Mejorar el concepto de sí misma de una mujer a mitad de su ejercicio profe- sional a través del asesoramiento para la construcción de la carrera}

Este artículo informa sobre el asesoramiento de construcción de la carrera en una mujer de mediana edad seleccionada a propósito, a mitad de su ejercicio profesional. Se llevó a cabo un diseño de investigación utilizando el estudio del caso único. Los datos se recogieron mediante un enfoque integrador cualitativo y cuantitativo. Después de la intervención, la participante exhibió un mayor sentido de autoconciencia. El asesoramiento para la construcción de la carrera se puede utilizar para ayudar a la mujer de mediana edad, a mitad de su vida ptofesional, a ser más consciente del significado que le asignó la vida y su visión de sí misma. Se necesitan investigaciones futuras con diversas mujeres de mediana edad, a mitad de su vida profesional (individualmente o en entornos grupales), para establecer la efectividad y los resultados a largo plazo del tipo de intervención que se ha aplicado en este caso.

\section{Introduction}

The twenty-first-century world of work is affected by a global change in the nature of work. Savickas et al. (2009) argue that most people nowadays live in knowledge societies. This has implications for the way individuals view their career, as the latter is no longer one lifelong venture. Instead, executing a career may be considered a constantly changing course and in need of continuous negotiation and re-definition, where individuals take responsibility for managing their own life and work. A postmodern global economy requires that career counselling professionals be mindful of the necessity of a flexible career choice, lifelong learning, the development of skills and competencies, and the creation of their own employment opportunities. Modern approaches may no longer suffice as the only approach for postmodern clients. Individuals are increasingly confronted with the need to understand their social 
identity and sense of self during continued changes in their work life. The nature of careers in current society is thus pertinent to all people who navigate their sense of self as part of the process of managing their own lives. This includes women in their midlife, who need to redesign their careers to keep up with such transformations and changes (Nortjé, 2019).

\section{Midlife/mid-career}

Developmentally, individuals are understood to grow and change over time from birth to death. Their development occurs a horizontal continuum but is also seen as vertical growth - described in layers of thinking about themselves, others, and society - and as an unconscious move towards the amalgamation of an authentic self (Wells, 2011). Career development is viewed as a process of individual development, over time, in relation to the meaning given to various life roles that can be seen as the 'formation and implementation of self-concepts within occupational contexts' (Schreuder \& Coetzee, 2013, p. 114). Duckworth (2016) posits that dealing with changes and challenges associated with midlife and mid-career can be considered a developmental process and Savickas (2002) describes midlife as a stage when the individual needs to cope with change and manage transitions. Savickas (1997) further describes career adaptability as the readiness to cope with predictable and unpredictable tasks and changes. International studies (Bond, 2009; Newton \& Stewart, 2010) have shown that the midlife or mid-career stage of life can be both a joyful time and a time of suffering for many women.

\section{Female midlife/ midcareer}

Midlife and midcareer can be a particularly challenging period for many women, seeing that physical as well as psychological changes are natural occurrences during this time. These changes are often accompanied by a shift in focus and priorities. According to Bond (2009, p. iii), the '[m]idlife journey can be experienced as a transformational process, changing the course of one's life.' Career development for midlife mid-career women may become more complex when they are confronted with feelings of anxiety and insecurity, provoked by die twenty-first-century world of work (Savickas, 2012a). They must deal with challenges such as irregular work hours, lack of equity in promotion decisions, lack of equity in pay, and conflicting family responsibilities (Rani \& Singla, 2015). Likewise, mid-career transition difficulties experienced by women may include finding an employment niche, deciding how to enhance their skill sets and not being able to afford training programmes (Newby, 2016). In addition, Kroger (2018) argues that 'many women at midlife had experienced limited identity-defining options in their late adolescent and early adult years' (p. 338). Yet, limited research exists regarding later-life employment and the experience of midlife transitions of women (August, 2011; Duckworth, 2016). Wells (2011) explains that research studies prior to the end of the twentieth century excluded female participants in the belief that findings describing men's development could be generalised to women. Gilligan (1982) argues that women enter 
midlife with 'a psychological history different from men's and face at that time a different social reality having different possibilities for love and for work, but they also make a different sense of experience, based on their knowledge of human relationships' (p. 173).

Newton and Stewart (2010) state that many women experience changing circumstances during the midlife period and circumstances differ for everyone, leading to different concerns and outlooks as they age. Women in their midlife experience biological changes that become especially challenging for them in a society where women's personal worth is often based on physical appearance (Ridout, 2012). Changes in family roles such as children leaving home and ageing parents needing care often occur during midlife. DePaolo (2015) believes that the key difference between genders vests in the fact that women's social roles generally bear more prominence in their lives than males' social roles. Women's connectedness to those around them can be seen in both their personal and professional lives, leading Duckworth (2016) to name the relational component of a woman's development as a hindrance to career progression, since it 'is seen as character weakness based upon the male developmental model' (p. 43). DePaolo (2015) states that women's sense of identity is linked to relational aspects and their connections to others. He explains that female identity is tied to nurturing and an ongoing challenge to find a balance between serving the needs of others and attending to her own needs, desires, and ambitions. Levinson (1996) believe that women become more assertive with the acceptance of autonomy in an effort to reconcile the masculine and feminine parts of the self.

It can thus be said that midlife, for women, is a significant period of career and personal development. This stage involves a search for meaning amidst occupational and family challenges and changes (Wells, 2011). Contextual as well as personal factors such as financial status, physical decline, health problems, discrimination, eldercare obligations, diminished job attachment, and negotiating the fulfilment of their own needs and those of others (August, 2011), all play a role in women's lives during this time of transition and transformation. Women in midlife are provided the opportunity to change and grow towards a more authentic self (Wells, 2011).

\section{Sense of self}

A person's sense of self refers to the developing awareness of who a person believes he/she is (Maree \& Molepo, 2016): a picture of the self that is socially created, shaped by culture, and narrated by language (Savickas, 2006). According to Maree (2016a, 2016b), the sense of self refers to personal and social identity, which includes the preservation and furtherance of the person's life script. Maree and Molepo (2016) describe the sense of self as a person's awareness of who she believes she is. This awareness is constructed via self-attributes (Giannantonio \& Hurley-Hanson, 2006) that provide information during decision-making (Savickas, 2002). To make meaning of life and enhance a person's sense of self, lie at the core of career construction counselling (Chen, 2011). An individual constructs a sense of self through narrating his/her knowledge and experiences during social interactions. 
Maree (2020) states that self- and career construction advances finding personal meaning in one's career and underpins the narrative assessment process.

\section{Moving from a traditional to a postmodern approach}

The postmodern approach evolved from career guidance that focused on the self as subject and was preceded by vocational guidance that focused on the self as object (Savickas, 2019a). Within the postmodern approach, integrating the objective measures of traits, abilities, and skills with qualitatively documented subjective stories would allow the best of both worlds to be drawn upon. Thus, counsellors use both psychometric tests and postmodern techniques to discover individuals' traits and the adaptation and development of these traits (from various contexts and within social interactions) allow them to discover and shape their unique life themes in accordance with their experiences (Hartung, 2010, 2011, 2013; Savickas, 2006). In our research study, we drew on subjective stories to gain a holistic picture of a woman in her midlife and mid-career. By recounting her career-life stories, the participant was able to draw a picture of how she functioned as a social participant in her own life story. Story development happened through the reflection on past, present, and future life experiences that related to her life roles. The assessment data (both qualitative and quantitative) were woven into the participant's story as meanings, patterns, and symbols that called for further exploration and ultimately new insight. Through this process of reflection, conscious knowledge was connected to subconscious advice (Maree, 2020). (While we also implemented a quantitative questionnaire, we interpreted its outcomes qualitatively only.) Systems theory and social constructionism were used as meta-theoretical frameworks for grounding the career construction theory.

\section{Principles and practice of career construction counselling}

Qualitative (narrative) approaches are particularly valuable in communities that experience a great deal of environmental complexity (Savickas, 2019a, b). Chinyamurindi (2016) emphasises the need to investigate how macro-environmental changes in South Africa (an extremely diverse, complex society) affect individuals and their career development-especially in the case of previously disadvantaged individuals such as women (Schreuder \& Coetzee, 2013).

According to Di Fabio and Maree (2013, p. 5), 'the world of work is constituted through personal construction against the backdrop of social reality'. Career construction is based on three theoretical principles, namely person/environment fit, individual development, and the narrative approach Savickas, 2019a. The general aim of career construction is to 'search for patterns of meaning in clients' lives' (Maree, 2013, p. 63). Patterns are extracted through narratives or stories that form part of the life design model.

Hartung (2011) describes the developmental stages of career construction theory and uses the 'rubrics of growth, exploration, establishment, management, and disengagement' for this purpose. Each stage consists of related tasks that entail 
adaptive goals. If these tasks are completed, they establish 'a foundation for success and future adaptability' (p. 108). Career adaptability can be increased in terms of (career) concern, control, curiosity, and confidence, all of which can support an individual to make successful transitions and effect positive change. Mid-career and midlife correlate with the management stage where the individual adapts to change (self and career) by either exploring new career possibilities or retaining and renovating current positions. In our research, the focus was on the sense of self of a woman in her mid-career and midlife as she adapted to changes in herself and in her career.

Career construction counselling involves an interpersonal process where the counsellor guides clients to author their career stories, making personal meaning pertaining to self and work (Hartung \& Vess, 2016). Maree (2013) describes career construction counselling as the approach used by a counsellor to guide a client in constructing life portraits by connecting life themes as elicited by means of postmodern techniques. The process consists of narrative methods including the Career Construction Interview (CCI) (Savickas, 2019) that prompt the individual to tell microstories. Small recollections and stories are woven together to form a life story that contains a central life theme. The narrative assessment process of career construction guides the individual towards self-construction and finding personal meaning in her life. Maree (2013, p. 38) states that clients 'actively construct themselves by conversing during social communication'. Those clients also use their own stories to establish or "'hold" themselves; to restore their sense of self' (Maree, 2013, p. 52). When they come to a crossroads in their lives, they need to design a new holding environment. Therefore, when clients reflect and think back on their life story, they can redesign it and make needed adjustments to restore their sense of self. This notion holds equally true for a woman in the mid-career stage of her life.

\section{Career construction counselling outcome research}

Narrative approaches to career counselling can offer new and distinctive perspectives on the concerns of a client who seeks counselling. Career construction counselling involves a counsellor guiding a client to move from deconstructing small stories to constructing a preferred story. This process gives clients the opportunity to authorise their stories and eventually enables them to 'advise themselves on how best to deal with crossroads that inevitably entail making career choices' (Maree, 2013, p. 45).

Outcomes of career construction counselling have been documented in the literature. For example, Maree (2016a, 2016b) found the use of career construction counselling to be effective in working with a woman in her mid-twenties, specifically finding that reflecting on career choices and life history resulted in decreased career indecision and increased insight into herself and her career. Santilli et al. (2019) conducted a group career construction intervention with 108 participants and described the results as indicating increased career adaptability and increased future orientation. Later, Mitts (2020) compared career construction and traditional career counselling and noted that both are effective career counselling interventions that 
reveal increased reflexivity, augmented sense of meaning in life, enhanced psychological health, and increased career optimism.

\section{Systems theory and social constructionism}

Individuals are embedded in systems and subsystems (system theory) and he/she constructs and gives meaning to reality (social constructionism theory) within specific contexts. In the study, the sense of self of a midlife, mid-career woman was investigated within the theoretical paradigms of systems theory, social constructionism theory, and career construction theory. The systems theory framework views the individual as nested in a hierarchy of systems and subsystems that interact with and influence one another reciprocally (Patton et al., 2006). Whatever influences one part of the system influences the whole system. Interference in one system has a ripple effect that reaches other systems and influences future chapters of an individual's career and life story. Systems theory guided the focus on the participant's experience of her unique context, while social constructionism acknowledges the meaning that she assigned to her experiences (reflected in her subjective and objective sense of self). Self- and career construction theory integrates differential, developmental, and dynamic perspectives to generated data and thus enables the mid-career, midlife woman to construct her own life story.

Systems theory was used as a lens through which the study focused on the experience of the participant in her unique context (including the influence of life design counselling on her contextual experience). Social constructionism can be distinguished from constructivism in that constructivism focuses on an individual's learning that takes place as the individual engages cognitively in the construction of knowledge. Social constructionism, on the other hand, focuses on the social aspect of interactions in a group where the individual gives meaning to his or her social and psychological world through social interactions (Young \& Collin, 2004). Social constructionism theory contends that individuals construct their knowledge and reality through language, social interaction, and relationships within specific contexts. Social constructionist theory is grounded in the assumption that the individual actively constructs meaning and knowledge through relationships and social interaction that take place within specific contexts (Maree, 2010). 'Individuals are not considered as passive objects, ultimately guided by external forces, but as proactive agents whose main activity consists of self-organization' (Di Fabio \& Maree, 2013 , p. 5). The individual's unique story is socially constructed, and dealing with it requires reflexive construction, deconstruction, co-construction, and reconstruction (Maree, 2013). Individuals construct themselves, within their context by the way they relate to themselves within a given moment, in a given society (Crous, 2011). Counsellors therefore focus on and acknowledge the meaning that individuals assign to experiences. The narrative assessment process provides the individual the opportunity to express and assign meaning to recollections and personal stories. Patton (2007) describes the systems theory framework as a vehicle to operationalise social constructionism because of its focus on the individual, as well as the multiple influences at play on the individual's career development. 
Savickas (2006) defines career construction theory as a theory that seeks to explain career and vocational behaviour and argues that '[i]t seeks to be comprehensive in its purview by taking three perspectives on vocational behaviour: differential, developmental and dynamic' (p. 35). He explains that career construction theory as a theoretical lens would assist the counsellor or researcher to consider the following three aspects: (1) What does an individual prefer to do based on his/her personal trait(s)? (2) How can an individual adapt these traits to cope with vocational changes? (3) Why do individuals move in distinct directions as shown in life themes? Career construction theory thus provides the foundation to view the individual as a social being who displays dispositions linked to related types of work environments and who can use self-defining narratives to reflexively form their career and their sense of self. Individuals are viewed as the sole expert on themselves while the counsellor becomes the co-author assisting individuals in writing their career stories, thus co-constructing preferred career stories through dialogue (Crouse, 2011). Patton et al. (2006) furthermore explain that the counsellor helps the individual to narrate a coherent story to authorise their career, identify themes in the life story to discover meaning, and acquire the necessary skills for performing the next chapter thus being able to negotiate transitions within the twenty-first-century world of work.

\section{Aims of the study}

Our decision to undertake the proposed study was urged by personal interest and the personal experiences of the second author, as well as by the fact that limited research exists in this field. Both researchers have come to realise that many ordinary women find the midlife and mid-career period a stressful or painful experience. The personal motivation and interest of the second author stemmed from how she perceived older women to experience midlife when she, as a teenager, noticed how her own mother struggled to make meaning of her life during her midlife years.

Little has been written specifically regarding women who experience mid-career challenges. The bulk of the literature dealing with career construction counselling focuses on younger individuals on the threshold of a work career. In South Africa, researchers have been investigating career construction as an appropriate perspective from which to approach career counselling. The bulk of the literature dealing with career construction counselling focuses on younger individuals on the threshold of a work career (Crous, 2011; Maree \& Hansen, 2011; Joffe, 1999). Hansen (2010) found that through life design counselling, an unwed pregnant teenager was able to come to new perspectives about her unique context. More than a decade earlier, Joffe (1999) had concluded that this approach could assist adolescents to find their own voice in and take responsibility for their career planning. Crous (2011) found that life design counselling had a positive impact on a black abandoned adolescent in that she became more aware of the meanings she assigned to her situation, what motivated her and her view of herself. We therefore assume that studying a woman's sense of self during mid-career change can expand the current body of knowledge on career construction counselling. Since the life design theory does not involve 
only a single event of career counselling before a career starts, but encompasses a process of constructing a life, we assume that such counselling is necessary at any age or point in life (e.g. also during the mid-career phase of an adult woman).

This study was also motivated by the researchers' concern that a woman facing mid-career challenges could be marginalised and ostracised when society does not provide a holding environment for the individual (August, 2011; DePaolo, 2015). This might even be more prominent during times of isolation (such as during the Covid-19 pandemic) as this woman could very well feel trapped and ignored within the community. As the working population ages, the representation of older woman is growing within the workforce (Austen \& Ong, 2009). Women in the midlife/ midcareer phase of their life are active members of the workforce, contributing constructively to the economy. We consider that this case study can contribute to a better understanding to these ethical, social, and economic issues and in doing so contribute to the knowledge needed to support woman in their midlife/ mid-career. The purpose of the study was to examine the value that career construction counselling has for a mid-career, midlife woman trying to establish her sense of self. The following (exploratory) questions guided the research, namely: (1) What influence does midlife have on the sense of self of a mid-career woman? and (2) How does career construction counselling influence the sense of self of a mid-career woman?

\section{Methods}

\section{Participant and context}

The specificity of the criteria for inclusion necessitated the use of a single-case intervention. The following served as criteria for the inclusion of this individual:

- A female between the ages of 45 and 55 (midlife and mid-career stage).

- A person who has expressed a need for career construction design and counselling.

Bea (a pseudonym was used to protect the identity of the participant) was a 48-year-old, Afrikaans-speaking, white female who lived with her husband and three children in a moderate-to-low socio-economic suburb on the fringe of urban development. According to the Statistics South Africa (2020), unemployment affected more than 43,1 percent of the workforce in 2020. Bea and her family were impacted by this financial hardship when her husband was retrenched six months before the intervention and therefore her salary was the family's main source of income. Research done within South Africa highlights how occupational racial and gender disparities as well as patterns of discrimination influence career opportunities (Booysen \& Nkomo, 2010; Parashar, 2014). However, research on white middle-aged women who struggle with finances has received scant attention within the South African context. Employed as a pre-school teacher working with 2- and 3 -year-old children, she had been working on and off as a pre-school teacher for the past 25 years. In the beginning of 2018, Bea started studying towards an N4 
teaching certificate through a distance education institution, as it became a requirement of her current employer. On a previous occasion, Bea enrolled for a teaching certificate but was unable to complete it due to her second pregnancy and the family being relocated. Bea did not study further after she finished high school as she explained that her parents did not have the money to fund her and that they expected her to find employment. She mentioned feeling forced to study as she needed a qualification for her to be able to stay employed. She also stated that she did not believe that she would be able to study. Bea expressed a need for career guidance in order to make a decision about her future, as she expressed a need for change. Maree (2020) describes five kinds of career indecision difficulties: (i) a lack of and need for career choice information, (ii) an inadequate sense of self, (iii) inability to make career choice, (iv) career choice anxiety, and (v) disagreement with others. At the time Bea entered the study, she overtly expressed her need for information as she wanted to know more in order for her to feel empowered to make a choice. Furthermore, she doubted her own knowledge and ability to make a sound decision and this presented as an inadequate sense of self.

The data-gathering opportunities involved face-to-face meetings with the participant during eight interwoven yet distinct sessions that were conducted over a period of two months during the second part of 2018. These intervention sessions focused on the analysis and synthesis of data with the aim of clarifying the problem presented, identifying what the participant was hoping to achieve, exploring the participant's sense of self, as well as exploring new perspectives regarding the participant's sense of self to enable her to be more adaptable within her midlife, mid-career circumstances (Savickas et al., 2009). The primary researcher and participant met for weekly sessions that varied in length between approximately one and three hours, depending on the participant's needs, understanding, and work pace.

Cardoso et al. (2020) describe three phases within which the goal of career construction counselling can typically be achieved. During the first phase, the participant formulates their career problem and explores the narratives that formed their current personal constructs (Maree, 2020, 2021). In this study, the first phase consisted of five sessions. The first two sessions (introductory interview and compiling a collage) were focused on building a trusting relationship between the participant and the researcher and in doing so explored her unique career problem. The third session consisted of the creation and discussion of a lifeline. The researcher and participant identified and engaged in patterns and themes elicited from the participant's recalled milestone experiences. During the fourth session, the Career Interest profile (CIP) (Maree, 2017a) was administered to gain a deeper understanding of the participant's career preferences as part of her life story. The participant was asked to draw a family constellation during the fifth session to explore characteristics and influence of family members. Cardoso et al. (2020) state that in the second phase, the individuals 'identify life themes and reconstruct the micronarratives into a macronarrative that revises the career story' (p. 189). In the current study, the second phase consisted of two sessions during which the researcher administered the Career Construction Interview (CCI) and the CAAS-SA (Maree, 2012), respectively. The CCI was administered to comprehend and co-construct the participant's life story and the CAAS-SA was administered to discover her possible psychosocial adaptability resources that 
could be utilised for managing midlife and mid-career transitions. The third phase culminates in an opportunity for the participant and the counsellor to draw in the new constructed story to formulate career plans and perform change (Maree, 2020). The eighth and final session was utilised to co-construct the participant's life story, as a meta-reflective opportunity for the participant to advise herself as primary expert on herself. Although it is possible to conduct the three phases within three individual sessions, Maree (2020) advises that 'The unique situation and needs of assessees will be the key considerations that determine the number of sessions in each of the counseling for self- and career construction phases' (p. 59).

The data generation process predominantly included qualitative techniques based on career construction counselling principals. This included observations, interviews, collage ('Who am I?'), lifeline, family constellation, the Career Construction Interview (CCI) (Savickas, 2019b), the Career Adapt-Abilities Scale-South Africa (CAAS-SA; Maree, 2012) and the Career Interest Profile (CIP, Version 6) (Maree, 2017a).

\section{Quantitative measure}

The Career Adapt-Abilities Scale-South Africa (CAAS-SA; Maree, 2012). The $C A A S-S A$ consists of 24 items, four scales, and six items per scale. It measures (career) concern, (Career) control, (career) curiosity, and (career) confidence-psychosocial resources that expedite managing transitions, accomplishing developmental tasks, and coping with work-related traumas. The psychometric properties of the $C A A S-S A$ are good. This includes reliability and cross-national measurement equivalence (Maree, 2012).

\section{Qualitative assessments}

The Career Construction Interview (CCI) (Savickas, 2019b) was implemented as both a data-gathering technique and a career counselling strategy, as it promoted the career construction process through a series of questions. The first question, 'How can I be useful to you?', is used to initiate the conversations and provokes responses that give insight into the participant's expectations of the intervention. The participant expressed her need for career choice information as she stated: 'I want to be exposed to more professions' $(6 ; 68 ; 7)$ and 'let me think about more careers' $(6 ; 68,13)$. The participant was then asked to elaborate on people she admired during her youth. In her youth, Bea admired a famous singer because 'she was a mother and she was a successful singer' $(6 ; 69 ; 37)$ pointing to the tension within her that she wants to be both a mother and have a career, driving her to the intension to do everything in her power to be successful in her career. Bea was also asked to name her favourite magazine, favourite TV programme, favourite website, and favourite book or movie and to give three favourite quotations. Answers to these questions elaborate on people's 'self-concepts and central life goals, the environments that fit clients' lifestyles' (Savickas, 2015, p. 3) and elicit provide self-advice on solving similar challenges as faced by the characters. Discussing her favourite book (Fiela se kind [Fiela's child]), Bea talked about the main character 
who was poor and had to raise a child. She described the character's strengths as having faith, working hard, and having perseverance, pointing to the advice she would give herself. Her own pain and hardship in terms of continued financial distress and need to care for her children becomes the driving force that motivates her to seek and acquire change. The last question, which asked the participant to describe her three earliest recollections, focused on revealing key challenges and advice to herself.

The Career Interest Profile (CIP, Version 6) (Maree, 2017a) was used to gather additional qualitative data. Based predominantly on Savickas' career construction theory (Savickas, 2019a) but also on Adler's (1933) holistic theory of personality, psychopathology, and psychotherapy, Cochran's narrative approach to career counselling (1997), and Erikson's (1982) theory of psychosocial developmental, the CIP reflects the differential, developmental, and narrative traditions. The CIP is a qualitative assessment instrument that comprises four parts (see Table 1).

\section{Procedure}

Assessment of the sense of self and interventions to develop the sense of self were intertwined and allowed the researcher to immediately deal with any obstacles that might arise during the sessions_-rather than to implement interventions after having analysed the data. The procedure (in terms of descriptions of the sessions) is summarised in Table 2.

\section{Data analysis}

An adapted version of Braun and Clarke's (2006) thematic analysis strategy was used to facilitate the analysis of the data. The main steps followed in analysing and interpreting the data are depicted in Table 3.

\section{Rigour of the study}

To enhance and increase the quality and trustworthiness of the research, credibility, confirmability, transferability, and dependability were promoted (Riege, 2003) (Table 4).

\section{Ethical issues}

The researchers obtained written informed consent from the participant for the anonymous reporting of the findings. The University's review board approved the research.

\section{Results}

Seven main themes and several subthemes emerged from the data. These themes and subthemes are explicated below. Verbatim quotes from dialogical extracts are provided to substantiate these quotes. We used a three-digit coding system to reference 


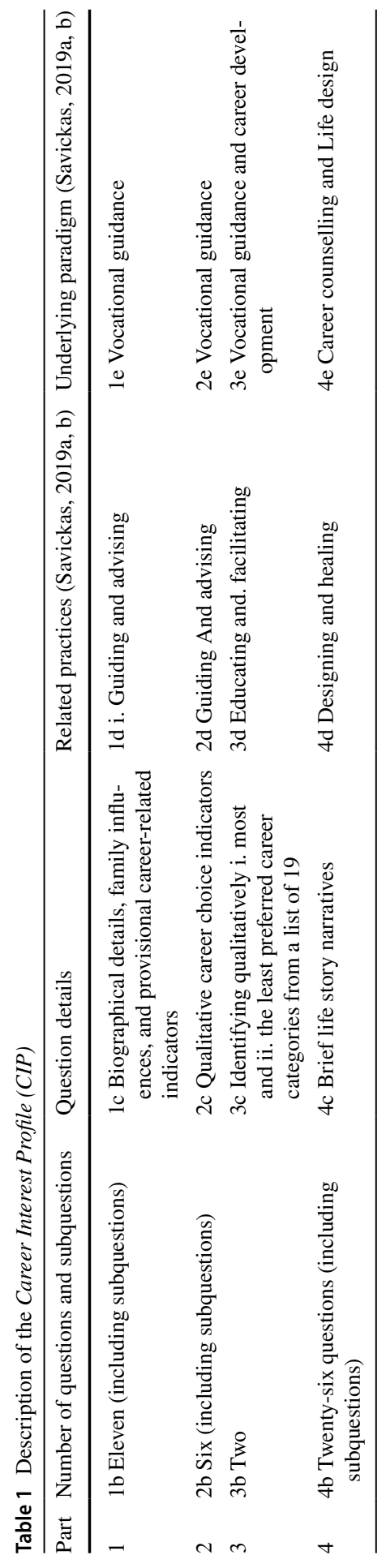




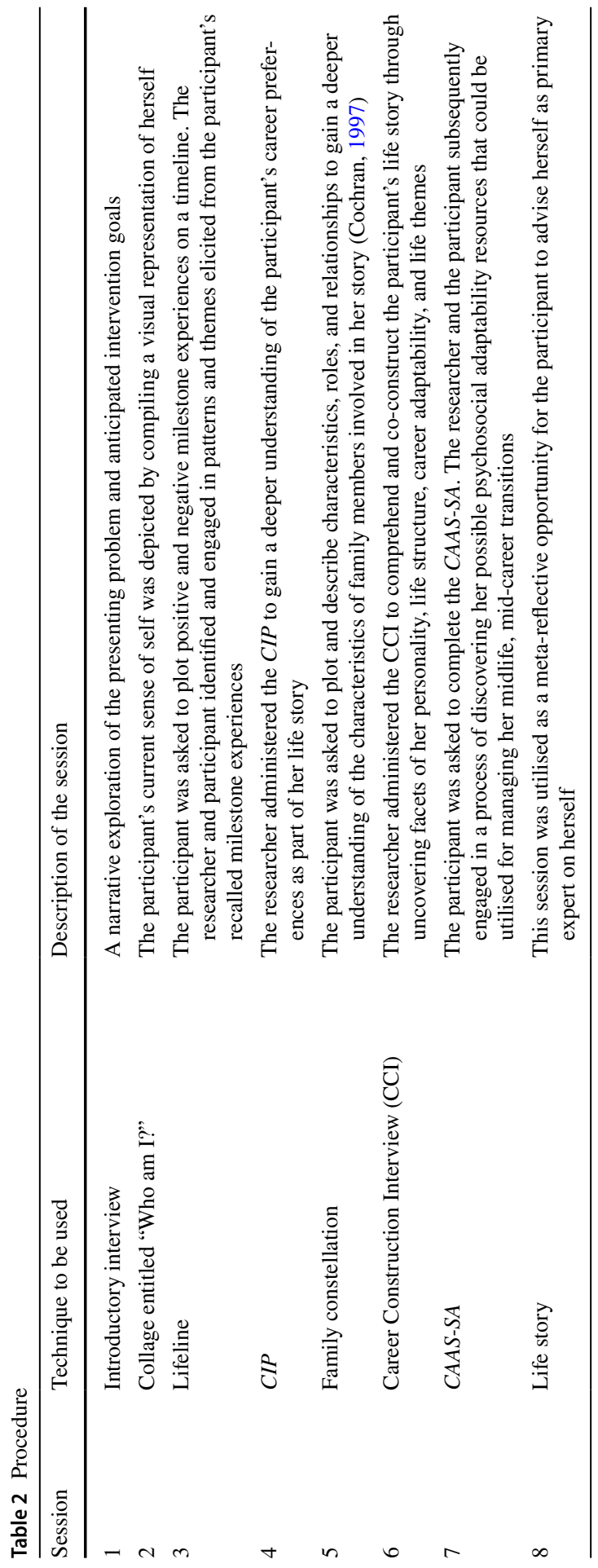


Table 3 Data analysis steps followed in this study

\begin{tabular}{ll}
\hline Data analysis steps & Description of data analysis steps \\
\hline Planning for recording of data & $\begin{array}{c}\text { The researcher had to plan beforehand to record data in } \\
\text { a systematic manner that would be appropriate for the } \\
\text { participant and the setting } \\
\text { Data were analysed both during generation at the site and } \\
\text { in-between contact sessions away from the site. Initial } \\
\text { ideas emerged for making sense of the data. Caution was } \\
\text { taken not to rush to premature conclusions } \\
\text { Data had to be organised into file folders and computer } \\
\text { files. An inventory was made and updated throughout the } \\
\text { sessions to keep a record of what had been gathered and } \\
\text { what still needed to be obtained } \\
\text { After transcribing the data, the researcher read and reread } \\
\text { the data and jotted down some initial ideas to get a gen- } \\
\text { eral sense of the information and to reflect on the overall } \\
\text { meaning } \\
\text { Once meaningful segments were identified, a label or code } \\
\text { was assigned to each. Descriptive coding was utilised by } \\
\text { using a word or phrase to describe the topic discussed in } \\
\text { the segment of data } \\
\text { Theading and writing memos } \\
\text { Through careful winnowing of the generated data (from } \\
\text { different sources), the researcher identified the most } \\
\text { prominent and occurring themes and subthemes related } \\
\text { to the midlife, mid-career woman's sense of self as part } \\
\text { of her life story } \\
\text { Data were evaluated for their usefulness and centrality, and } \\
\text { to determine the plausibility of the researcher's develop- } \\
\text { ing understandings (De Vos et al., 2005) } \\
\text { The researcher critically scrutinised the emergent cat- } \\
\text { egories, patterns, themes, and subthemes, and looked } \\
\text { for alternative explanations for these elements and } \\
\text { the linkages among them. She subsequently aimed to } \\
\text { demonstrate why the explanation offered was the most } \\
\text { plausible one } \\
\text { The concluding step involved representing what was found } \\
\text { during the research process. The researcher integrated } \\
\text { research findings with personal conclusions, as well as } \\
\text { with the literature study that was conducted and theories } \\
\text { that were consulted }\end{array}$ \\
Generating categories, themes, and patterns \\
Testing the emergent understandings
\end{tabular}

data. The first digit refers to the session (indicating the data source-see Table 2), the second to the page number where the entry can be found, and the third digit refers to the line where it occurs.

\section{Theme 1: family/significant others' influence}

This theme refers to relevant content regarding the participant's family and other significant people in her life, which inherently influenced her sense of self. 


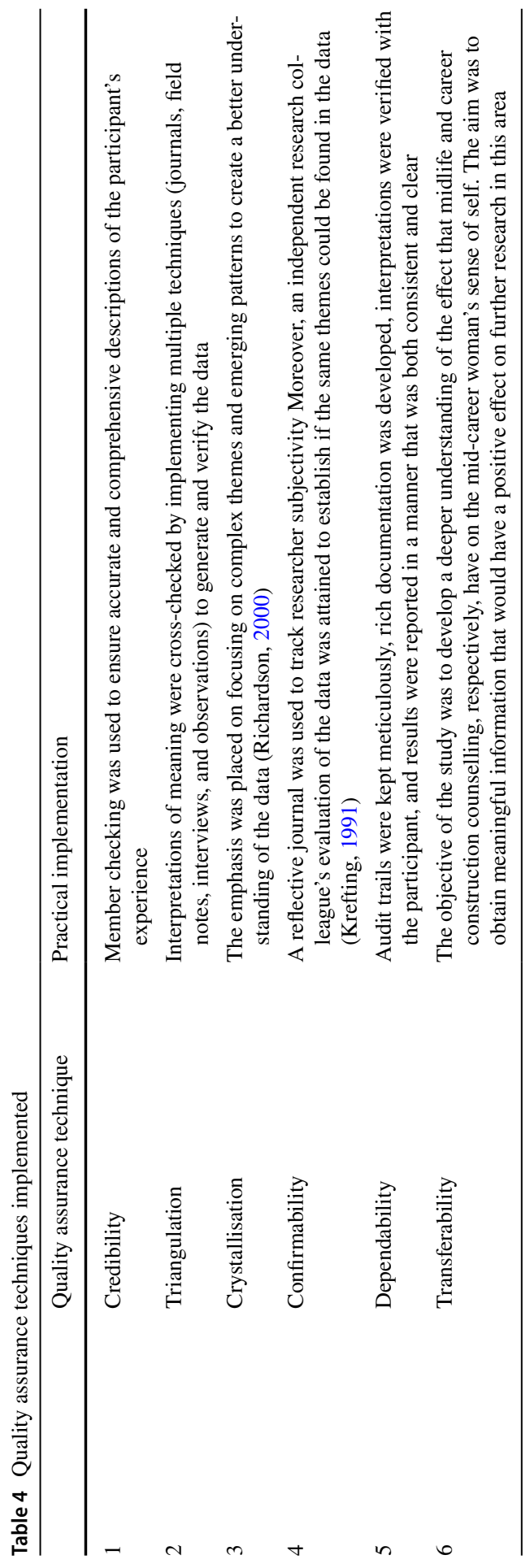


Influence of parents 'My parents encouraged me to find employment rather than to study because we do not have money to fund tertiary education' $(5 ; 54 ; 29)$.

Family relationships 'My children are particularly important to me' $(1 ; 8 ; 38)$.

The influence of others 'I sometimes choose something for myself and then think: What will other people think about that' $(2 ; 16 ; 17)$. 'My friend is everything to me, she understands. She is very dear to me' $(4 ; 43 ; 20)$.

\section{Theme 2: personal traits/characteristics}

This theme refers to habitual patterns of behaviour, thought, and action which could be observed in the participant.

Helping others 'I would break my back to help others' $(7 ; 79 ; 20)$.

Extroversion 'It makes me happy to be surrounded by people and friends and my family' $(2 ; 13 ; 11)$.

Self-esteem 'I care. I have that passion to take away heartache and I have a warm heart' $(2 ; 13 ; 10)$.

Sense of self-efficacy 'As I stuck the pictures I knew immediately where each one should go. It made me feel good. I thought: look at how much I have, how much I actually am' $(2 ; 21 ; 32)$.

Structure orientation 'I like everything that happens to be in an order. It has to be neat, it has to fit together' $(2 ; 13 ; 38)$.

\section{Theme 3: personal values}

This theme refers to principles or standards that activate, guide, and motivate the participant's behaviour.

Achievement 'It can be done, I know, I have done it' $(3 ; 24 ; 43)$.

Financial considerations 'thought I wanted to further my studies to be qualified in what I do, but again, it is finances that make me think I might not be able to' $(7 ; 80 ; 17)$.

Work pride 'But now it is teaching, teaching, teaching. I enjoy it and I can do it well' $(5 ; 55 ; 25)$.

\section{Theme 4: religion/spirituality}

This theme refers to relevant content that is indicative of the participant's belief in and worship of a personal God, and that includes spiritual beliefs regarding the meaning of life.

Communicating with God 'I said: God, how will we get out of this debt?, and then my husband gets a heart attack, and everything gets paid' $(3 ; 35 ; 45)$.

Trusting in the future 'I feel that I am on the right path, but at the bottom, on the lowest step. I have to move up' $(1 ; 7 ; 17)$.

Thankfulness 'Sometimes I cry to say thank you to God that He holds me in His hands, that I am precious to him' $(2 ; 14 ; 40)$. 


\section{Theme 5: management of midlife/mid-career challenges}

This theme contains content concerned with developmental tasks associated with the midlife/mid-career.

Awareness of the job market 'I knew at some stage they would come in and you would have to be qualified. I was actually kind of forced to study' $(1 ; 9 ; 1)$.

The importance of holding on 'It (studying) was I dream I had and I realised in the past year that it is important. I have to do it, for myself' $(1 ; 10 ; 13)$.

The need to update work-related skills ' $\mathrm{N} 4$ you have to do to work in a preschool with children aged 0 to 4 years old. Then you have to do N5 to work with 4- to 6-year-olds. With N6 you are allowed to teach older children' $(1 ; 6 ; 46)$.

Sense of innovation 'I want to complete N6 in order for me to work in a primary school' $(1 ; 10 ; 11)$.

\section{Theme 6: challenges}

This theme contains content that refers to experiences, situations, and emotions described by the participant as physically or emotionally distressing or difficult.

Traumatic experiences 'It is not nice when your husband has two heart attacks'(3;34;39).

Educational difficulties 'On this occasion I did not study well (as was always the case), therefore I did not do well as far as marks are concerned, especially in Mathematics and History. It was unnecessary, I did not need those subjects' $(6 ; 81 ; 32-35)$.

Emotional sensitivity; 'I know I should have written humble or gentle-with cry in brackets.' $(4 ; 42 ; 45)$.

\section{Theme 7: career adaptability}

This theme contains content related to career adaptability and the related subskills based on the CAAS (Savickas \& Porfeli, 2012).

Career concern 'I want (a qualification). N6 in order for me to move to a primary school' $(1 ; 10 ; 11)$.

Career control 'Now I am thinking about these things: what I want to become and what I do not want to become' $(5 ; 56 ; 19)$.

Career curiosity 'Expose me to more careers so that I can view myself in a different light and be capable of doing something different' $(6 ; 68 ; 14)$.

Career confidence 'I see that I am capable of being more than just a mother or teacher' $(6 ; 68 ; 9)$. 


\section{Discussion}

The purpose of the study was to examine the value that career construction counselling has for a mid-career, midlife woman trying to establish her sense of self. The research questions are reviewed in this section in the light of the findings that have emerged from the study. Literature related to life design-related counselling and enhanced sense of self, especially during midlife/mid-career, is used to compare our findings to previous findings.

\section{What effect does midlife have on the sense of self of a mid-career woman?}

Savickas (2012a, b) argues that midlife individuals, who find themselves within the management stage (Super, 1957) of career development, are likely to explore new roles as they sense their current positions to be unstable. The midlife question 'Do I want to do this for the next twenty-five years?' (Savickas, 2002, p. 179) causes the individual to ponder about whether to hold on to a current position or to let go. The findings of this study confirmed this view by indicating that the participant was experiencing her current position as unstable, putting her at a crossroads where she had to decide what she wanted to do from here. As a midlife/midcareer woman, she faced typical tasks, changes, and challenges relating to this developmental stage. She sought the advice of a counsellor as she expressed eagerness to participate in the career construction counselling proses, hoping to bring about change in her current circumstances: 'I was excited, I could not wait' $(1 ; 1 ; 36-37)$; 'I feel I have to do things differently' $(1 ; 1 ; 46)$. As she considered her age and her career path, she expressed uncertainty about her current position: 'I want to know if I am moving in the right direction' $(1 ; 7 ; 16)$ and 'I need to move up' $(1 ; 7 ; 19)$. Midlife changes and challenges brought her to a crossroads in her life where she had to consider what she wanted to do next. This was a time of personal assessment that held transitional opportunity for her.

As discussed in the literature review, midlife and midcareer can be filled with challenges and changes that directly and indirectly influence a woman's sense of self. The participant experienced midlife changes such as the restructuring of family roles (her children were reaching the point of leaving home), as well as possible changes in employment-she experienced the need to update her vocational skills by furthering her qualifications. Discussing the possibility of furthering her qualifications, the participant said 'It is a dream of mine ... I want to do it for myself' $(1 ; 10 ; 11-14)$. She described the significant role that her children played in her life as she stopped working every time she fell pregnant, wanting to be home with them. Bea also stated 'My children are particularly important to me ' $(1 ; 8 ; 38)$ and 'I would break my back to help others' $(7 ; 79 ; 20)$. DePaolo (2015) explains that a woman's sense of self-identity is linked to relational nurturing, as it creates an ongoing challenge of establishing a sense of balance between attending to her own ambitions and serving the needs of others.

This finding correlates positively with the finding that pointed to the dichotomy within the midlife woman's relational nurturing role: fulfilling her own needs versus 
serving the need of others. This dichotomy originally presents as tensions in her circumstances. For instance, she feels the strong need to care for her children as well as a need to improve herself 'I see that I am capable of being more than just a mother or teacher' $(6 ; 68 ; 9)$. Her tension is transformed into intention and an increase in her career options " $[\mathrm{t}] \mathrm{o}$ have the ability to enrol into a study field again and do something else' (6;68.9). She mentioned a sense of relief on account of her belief that the intervention had also enabled her to enhance her chances of finding suitable employment.

\section{How does career construction counselling influence the sense of self of a mid-career woman?}

Responding to the first question in the CCI, 'How can I be useful to you today?', the participant responded: 'Expose me to more careers so that I can view myself in a different light and that I am capable of doing something different' $(6 ; 68 ; 7-14)$. This response shed light on the crossroads she was facing: She sought guidance to learn more about different roles and possibilities for work and career change.

Through career construction counselling, the participant explored her personal and social identity and identified themes and strategies within her own life story that could support her in negotiating future life and career transitions. Her sincerity and acceptance of the process appeared to be increasing with each session, as she appeared to feel safe to express her views and feelings. Bea expressed her appreciation for the sessions and said 'I feel thankful that you help me and...I just connected with you' $(6 ; 71 ; 17-18)$. A study by Pitts and Miller-Day (2007) investigated researcher-participant rapport development in a sample of 16 field researchers and they uncovered five permeable stages in the process of rapport building. The authors considered the fourth stage-'Interpersonal connection' - as a phase characterised by 'increased reciprocity, intimacy, and risky self-disclosure ... fostering a partnership of two unique individuals balancing both personal and professional goals' ( $p$. 193). Halfway through the intervention, the rapport development reached a stage of interpersonal connection as she shared experiences and events that were most important to her; thoughts that only God knows about. She included the researcher-participant relationship and intervention sessions as a positive experience on her lifeline and ended the session by saying: 'This (session) was so good, I truly enjoyed it' (3; 40;15-16).

During the intervention, the participant increasingly articulated an enhanced sense self-efficacy by giving herself credit for being, for instance, kind, caring, avoiding conflict, thriving when surrounded by many people, and helping others. The participant became more aware of the reflective process, saying: 'Now I am thinking about these things and about what I want to do and what do not want to do' $(5 ; 56 ; 19)$. She gained greater knowledge about her own abilities, interests, and personality traits and obtained enhanced insight into the influence other people exerted on her personal life and career choices. Bandura (2006, p. 307) describes self-efficacy as 'people's beliefs in their capabilities to produce given attainments' and explains that people have different areas in which they nurture their efficacy. 
Reflecting on the collage she created she noted: ' I did not think I would be able to do this, but now I see... this is how I fit' $(2 ; 20 ; 42)$. After the third session, she reflected 'I am proud that I did something for myself... it made me realise that I do not have to stand back for other people' $(3 ; 39 ; 5)$. She displayed enhanced adaptability strategies and gained insight into her own coping mechanisms. She was able to reflect on her life story and voiced increased self-insight and self-confidence shown in her comment: 'I see myself in a different light. I am capable of being more than just a mother or just a teacher' $(6 ; 68 ; 9-10)$. Her doubt in her own abilities when confronted by her colleague supported the findings of a study conducted by Schyns and Collani (2002), which reported that the satisfaction of colleagues directly influences occupational self-efficacy. Karademas (2006) conducted a study with 201 participants researching the correlation between self-efficacy, social support, and wellbeing. The researcher concluded that self-efficacy (optimism and expectations) had an impact on cognitive representations and human functioning. The participant's ability to complete tasks when she felt supported and able to do so was in congruence with this research.

The research provided some guidelines on how the sense of self of a midlife/ midcareer woman could be enhanced. The findings confirm the view of Di Fabio and Maree (2013) and Nkambule (2010), who argue that the process of narrative career counselling brings about transformation. It facilitates a greater understanding of the value of meaning making and accomplishes personal agency, personal growth, and acceptance of personal responsibility in the career counselling process brought about change in her thought processes concerning herself and her ability to visualise and anticipate a meaningful future career. She became aware of the impact that her perceptions about herself and her experiences have on her decision-making strategies. She showed an increased capacity to learn about herself and her possible career roles in the world of work. Her ability to take the initiative and her capacity to become aware of career developmental tasks aided in enhancing her self-esteem and self-efficacy and ultimately enhanced her sense of self.

In summary, it seems that the results discussed in this section are usual findings in studies about the career construction interview (Savickas, 2019a, b). First, the intervention enabled the participant to become more aware. Second, it revealed the complexity of the participant's situation. Third, it clarified her (career-) identity. Lastly, it revealed the value of negotiating a participant's identity development in the context of her contextual facilitators and constraints. As shown above, the intervention advocated in this article enabled the career counsellors to make a specific contribution to the midlife issues of the participant.

\section{Results obtained from the administration of the CAAS-SA}

The results obtained from the pre- and post-administration of the CAAS-SA appear in Table 5. Information from the above table indicates that the participant's career confidence stayed the same - with a description of very strong-and demonstrated her capacity to pursue her own aspirations. The scores for both career concern and career control increased but remained in the descriptive category of strong. The 
Table 5 Career adapt-abilities scales-description

\begin{tabular}{|c|c|c|c|c|c|}
\hline \multirow[b]{2}{*}{ Subscale } & \multicolumn{2}{|c|}{ Pre-intervention } & \multicolumn{2}{|c|}{ Post-intervention } & \multirow{2}{*}{$\begin{array}{l}\text { Difference: Post- } \\
\text { score-pre-score }\end{array}$} \\
\hline & Score & Description & Score & Description & \\
\hline Concern & 17 & Strong & 21 & Strong & 4 \\
\hline Control & 19 & Strong & 22 & Strong & 3 \\
\hline Curiosity & 12 & Somewhat strong & 15 & Strong & 3 \\
\hline Confidence & 24 & Very strong & 24 & Very strong & 0 \\
\hline
\end{tabular}

career curiosity score increased and moved from 'somewhat strong' to 'strong'. The participant showed an increase in her capacity to learn more about herself and the roles she could fulfil in the world of work. The findings of this study confirmed the view of Savickas et al. (2009), namely that life-designing interventions can increase career concern, control, curiosity and confidence that relate to career planning, career choice, and work adjustment. Savickas (1997, p. 254) defines career adaptability as 'a readiness to cope' with both predictable and unpredictable changes related to the working environment. The participant obtained a lower score on the curiosity subscale, prior to intervention, which might have been indicative of her limited exploration of the world of work. According to Di Fabio and Maree (2013) and Hartung (2011), limited career exploration can inherently limit career expectations. Boding well for the participant's career adaptability was a very strong score in the career confidence scale, which indicated a sense of optimism in pursuing career aspirations, even when faced with obstacles and barriers.

The discussion above shows that, in career counselling sessions, it is possible and useful to use at the same time quantitative assessment measures and narrative assessment instruments. It also shows that it is possible to conceive identity as both stable and dynamic (adaptability).

\section{Specific findings regarding the mid-career of women}

Midlife and mid-career can be filled with challenges and changes that directly and indirectly influence a woman's sense of self. As a stage within individual and career development, midlife can be described as a unique period of growth (DePaolo, 2015; Duckworth, 2016; Wells, 2011) towards the amalgamation of an authentic self (Wells, 2011). It can also be observed in ways of thinking about oneself, others, and society. The participant experienced midlife changes such as the restructuring of family roles (her children were reaching the point of leaving home), as well as possible changes in employment-she experienced the need to update her vocational skills by furthering her qualifications. Midlife changes and challenges brought her to a crossroads in her life where she had to consider what she wanted to do next. This was a time of personal assessment that held transitional opportunity for her. As a mid-career woman, the primary researcher felt a kinship and was able to identify with the participant's story. The impact of being the breadwinner of a family and having vulnerable children who dependent on a mother can be a great source of 
tension. Doing this research highlighted the value of being able to look at key points in the primary researcher's own life and taking advice from how she dealt with difficult situations before provides her with strength to persevere when she experiences times of uncertainty.

\section{Possible advantage of proposed model}

Interventions premised on traditional career theories may not be sufficient to deal with constantly changing career environments or to address the needs of marginal workers (Maree, et al., 2018; Maree, 2016a, 2016b). Qualitative methods are recommended as particularly useful and necessary (in addition to quantitative methods) to comprehend the career development processes of individuals who are considered previously disadvantaged (Maree, 2010, 2017b, 2020)_as in the case of women. Disadvantaged people meet with difficulties in their career development that are not frequently and simply identified through the quantitative research paradigm.

\section{Limitations of the study}

First, the research lacked follow-up assessments to confirm the stability of our findings. Second, it is possible that the $C A A S-S A$ is not sufficiently sensitive to the changes taking place in people during the kind of intervention elaborated on here. Third, quality control criteria were put in place to ensure that credibility, confirmability, transferability, dependability, and trustworthiness were achieved. However, the subjectivity of our interpretations needs to be regarded as a limitation, as another researcher could well have interpreted the results and subsequent findings in a different manner. Fourth, the subjective nature of the data gathered from self-report questionnaires and journal entries could lead to the questioning of the trustworthiness of the answers provided by the participant. Fifth, if other researchers had conducted the study, there might have been variations in the results arising from researcher bias. We acknowledge that our preferred counselling style and our bias towards midlife women and the idiosyncratic challenges they face may have influenced us during the intervention. Sixth, the dual roles the primary research assumed (researcher and practitioner) may have influenced the outcomes (Hay-Smith et al., 2016). To reduce that possibility, we planned, executed, and monitored the methodology carefully. To prevent possible ethical challenges, we adhered to standard ethical guidelines meticulously. Moreover, a professional participant-practitioner relationship with the participant was sustained throughout the intervention (Kewley, 2006).

\section{Recommendations for theory development, research, and practice}

The research contributed to research in the field under discussion in a number of ways. First, it shows that the narrative process of reflection and meta-reflection enabled the participant to become more aware of the meaning she assigned to life. Second, it shed light on the complexity and nature of the changes and challenges she faced at this particular crossroads. Third, recounting her career-life story to 
and assisted by the researchers, clarified her identity and her view of herself, thus contributing to enhancement of her sense of self. Fourth, the article sheds some light on 'the negotiation between identity development and contextual facilitators and constraints' of a woman in midlife (Kroger, 2018).

Recommendations for future research include the following. First, psychologists in training should be exposed to the theoretical and practical aspects of the intervention and required to investigate its viability in diverse contexts. Second, longer-term research is needed to establish the long-term impact of career construction counselling techniques and interventions on various groups of participants. Third, psychologists should collaboratively conduct research to build on the evidence that career construction counselling, as meta-reflective intervention, facilitates people's experience of listening to their own advice when dealing with transitions and crossroads in their lives. Fourth, the use of different assessment instruments in research on career construction counselling should be considered. Fifth, it seems important to educate career counsellors to understand the challenges our participant faced and how such challenges affect the behaviour of midlife women so that they can intervene more effectively on behalf of their clients. This could enhance the co-construction of their career-life identity, together with co-construction of other aspects of their life stories. Lastly, networking with other researchers, designing research projects to examine the effectiveness of interventions, and reporting on outcomes in a broad array of scholarly journals, books, and book chapters and on various platforms (traditional and electronic) are essential.

\section{Conclusion}

Savickas (2019a) suggests that themes revealed by exploring people's life stories guide clients in making meaningful choices, enabling them to navigate transition phases. The current study confirmed the applicability of the intervention programme in this regard as the participant became more aware of the meaning she assigned to the challenges she faced, and her view of herself, ultimately enhancing her sense of self. We found career construction counselling to be an invaluable approach towards supporting this midlife woman at a crossroads in her personal and career life. The findings confirmed the belief of Savickas (2019b), namely that career construction counselling enables individuals to reflect on their life stories and in due course helps them to engage in actions to build future selves.

Lastly, we found career construction counselling to be a useful strategy during which reflection and guided meta-reflection enabled the participant to clarify her career identity by considering carefully both aspects that impede and factors that bolster her identity development. This culminated in her being better equipped to deal with the challenges and transitions of her own life. We conclude that it is important that career counsellors consulted by mid-career women should be more sensitive to and aware of the experiences of these women to assist them in enhancing their sense of self. 
Acknowledgements We thank the participant for taking part in the research. We thank Isabel Claassen for her scrutiny of the text. No financial support was received for the research.

\section{References}

Adler, A. (1933). What life should mean to you. Unwin Books.

August, R. A. (2011). Women's later life career development: Looking through the lens of the kaleidoscope career model. Journal of Career Development, 38(3), 208-236. https://doi.org/10.1177/08948 45310362221

Austen, S., \& Ong, R. (2009). Employment retention and re-entry among older women: Do health and caring roles matter? Paper at the 38th Conference of Economists, Adelaide, Australia.

Bandura, A. (2006). Guide for constructing self-efficacy scales. In F. Pajares \& T. Urdan (Eds.), SelfEfficacy Beliefs of Adolescents (pp. 307-337). Information Age Publishing.

Bond, J. M. (2009). Four women's stories of midlife transformation: An organic inquiry. (Unpublished master's thesis.) Institute of Transpersonal Psychology, Palo Alto, California.

Booysen, L. A., \& Nkomo, S. M. (2010). Gender role stereotypes and requisite management characteristics. Gender in Management: An International Journal, 25(4), 285-300. https://doi.org/10.1108/ 17542411011048164

Braun, V., \& Clarke, V. (2006). Using thematic analysis in psychology. Qualitative Research in Psychology, 3(2), 77-101. https://doi.org/10.1191/1478088706qp063oa

Cardoso, P., Savickas, M. L., \& Gonçalves, M. M. (2020). Facilitating narrative change in career construction counselling. Journal of Career Development, 29(1), 1-14. https://doi.org/10.1177/08948 45319898872

Chen, C. P. (2011). Narrative counselling: An emerging theory for facilitating life career success. In J. G. Maree (Ed.), Shaping the Story (pp. 20-38). Van Schaik.

Chinyamurindi, W. T. (2016). A narrative investigation into the meaning and experience of career success: Perspectives from women participants. SA Journal of Human Resource Management, 14(1), 1-11. https://hdl.handle.net/10520/EJC185050

Cochran, L. (1997). Career Counseling: A Narrative Approach. Sage.

Crous, S. (2011). Possibility and limits of life design counselling with an abandoned adolescent. (Master's thesis), University of Pretoria, Pretoria, South Africa

De Vos, A., Delport, C., Fouché, C. B., \& Strydom, H. (2005). Research at Grass Roots: For the Social Sciences and Human Services Professions (3rd ed.). Van Schaik.

DePaolo, K. A. (2015). The passion within: Challenging the feminine mystique by educating midlife women to fulfill their career dreams (Unpublished doctoral dissertation.) The University of Vermont and State Agricultural College, Vermont, New England.

Di Fabio, A., \& Maree, J. G. (2013). Psychology of Career Counseling: New Challenges for a New Era. Nova Science.

Duckworth, L. L. (2016). Coloring outside the lines: A heuristic exploration of midlife career change in women (Unpublished doctoral dissertation.) ProQuest LLC, Ann Arbor, Michigan.

Giannantonio, C. M., \& Hurley-Hanson, A. E. (2006). Applying image norms across Super's career development stages. The Career Development Quarterly, 54(4), 318-330. https://doi.org/10.1002/j. 2161-0045.2006.tb00197.x

Gilligan, C. (1982). In a Different Voice: Psychological Theory and Women's Development. Harvard University Press.

Hartung, P. J. (2011). Career construction: Principles and practice. In K. Maree (Ed.), Shaping the Story: A Guide to Facilitating Narrative Career Counselling (pp. 103-120). Sense.

Hartung, P. J. (2010). Career assessment: Using scores and stories in life designing. In K. Maree (Ed.), Career Counselling: Methods That Work (pp. 1-10). Juta.

Hartung, P. J. (2013). Career Construction Counseling. In A. Di Fabio \& J. G. Maree (Eds.), Psychology of Career Counseling: New Challenges for a New Era (pp. 15-28). Nova Science.

Hartung, P. J., \& Vess, L. (2016). Critical moments in career construction counseling. Journal of Vocational Behavior, 97, 31-39. https://doi.org/10.1016/j.jvb.2016.07.014

Hay-Smith, E. J. C., Brown, M., Anderson, L., \& Treharne, G. J. (2016). Once a clinician, always a clinician: A systematic review to develop a typology of clinician-researcher dual-role experiences in health 
research with patient-participants. Medical Research Methodology, 16, 95. https://doi.org/10.1186/ s12874-016-0203-6

Karademas, E. C. (2006). Self-efficacy, social support and well-being: The mediating role of optimism. Personality and Individual Differences, 40(6), 1281-1290. https://doi.org/10.1016/j.paid.2005.10.019

Krefting, L. (1991). Rigor in qualitative research: The assessment of trustworthiness. American Journal of Occupational Therapy, 45(3), 214-222. https://doi.org/10.5014/ajot.45.3.214

Kroger, J. (2018). The epigenesis of identity—what does it mean? Identity, 18(4), 334-342. https://doi.org/ 10.1080/15283488.2018.1523730

Levinson, D. J. (1996). The Seasons of a Woman's Life. Knopf.

Maree, J. G. (2010). Brief overview of the advancement of postmodern approaches to career counseling. Journal of Psychology in Africa, 20(3), 361-367. https://doi.org/10.1080/14330237.2010.10820387

Maree, J. G. (2012). Career Adapt-Abilities Scale: South African form: Psychometric properties and construct validity. Journal of Vocational Behavior, 80(3), 730-733. https://doi.org/10.1016/j.jvb.2012.01. 005

Maree, J. G. (2013). Counselling for Career Construction: Connecting Life Themes to Construct Life Portraits: Turning Pain Into Hope. Sence.

Maree, J. G. (2016). Career construction as a way of resolving career indecision. South African Journal of Higher Education, 30(3), 170-192. https://doi.org/10.20853/30-3-665

Maree, J. G. (2016b). Career construction counseling with a mid-career black man. The Career Development Quarterly, 64(1), 20-34. https://doi.org/10.1002/cdq.12038

Maree, J. G. (2017a). Career Interest Profile (Ver. 6). CIP Technical Manual (Version 6). JvR Psychometrics

Maree, J. G. (2017). Mid-career construction counselling to instil spiritual awareness and allay fear. South African Journal of Education, 37(4), 1-10. https://doi.org/10.15700/saje.v37n4a1443

Maree, J. G. (2020). Innovating Counselling for Self- and Career Construction: Connecting Conscious Knowledge with Subconscious Insight. Springer.

Maree, J. G. (2021). The psychosocial development theory of Erik Erikson: critical overview. Early Child Development and Care 191(7-8), 1107-1121. https://doi.org/10.1080/03004430.2020.1845163

Maree, J. G., Cook, A. V., \& Fletcher, L. (2018). Assessment of the value of group-based counselling for career construction. International Journal of Adolescence and Youth, 23(1), 118-132. https://doi.org/ 10.1080/02673843.2017.1309324

Maree, J. G., \& Hansen, E. (2011). Identifying and dealing with the adaptability needs of an unwed pregnant teenager. Journal of Psychology in Africa, 21(2), 211-219. https://doi.org/10.1080/14330237. 2011.10820449

Maree, J. G., \& Molepo, J. M. (2016). The use of narratives in cross-cultural career counselling. In M. McMahon \& W. Patton (Eds.), Career Counselling: Constructivist Approaches. Routledge.

Mitts, N. G. (2020). Crafting a Career Narrative: A Comparison of Career Construction and Traditional Career Counseling. (Doctoral dissertation, Indiana University)

Newby, J. M. (2016). Evaluation of the effectiveness of a career development intervention program for adults in mid-career transition (Doctoral dissertation), Fielding Graduate University, Santa Barbara, California

Newton, N., \& Stewart, A. J. (2010). The middle ages: Change in women's personalities and social roles. Psychology of Women Quarterly, 34(1), 75-84. https://doi.org/10.1111/j.1471-6402.2009.01543.x

Nkambule, T. L. C. (2010). The career adaptability of a young Swazi woman. (Unpublished master's thesis.) University of Pretoria, Pretoria, South Africa

Nortjé, M. (2019). Enhancing the sense of self of a mid-career woman through career construction counseling. Unpublished mini-dissertation. University of Pretoria, Pretoria, South Africa

Parashar, S. (2014). Marginalized by race and place: A multilevel analysis of occupational sex segregation in post-apartheid South Africa. International Journal of Sociology an Social Policy, 34(11/12), 747-770. https://doi.org/10.1108/ijssp-01-2014-0003

Patton, W. (2007). Connecting relational theory and the systems theory framework: Individuals and their systems. Australian Journal of Career Development, 16(3), 38-46. https://doi.org/10.1177/1038416207 01600307

Patton, W. A., McMahon, M. L., \& Watson, M. B. (2006). Career development and systems theory: Enhancing our understanding of career. In G. B. Stead \& M. B. Watson (Eds.), Career Psychology in the South African context (pp. 65-78). Van Schaik.

Pitts, M. J., \& Miller-Day, M. (2007). Upward turning points and positive rapport-development across time in researcher-participant relationships. Qualitative Research, 7(2), 177-201. https://doi.org/10.1177/ 1468794107071409

Rani, N., \& Singla, J. (2015). Conceptualizing Women's Working Lives: Career Concerns or Social Comparison. International Journal of Management Prudence, 7(1) 
Richardson, L. (2000). New writing practices in qualitative research. Sociology of Sports Journal, 17, 5-20. https://doi.org/10.1123/ssj.17.1.5

Ridout, N. K. (2012). Personality as a Protective Factor in Women's Transition to Midlife (Doctoral dissertation), Alliant International University, California School of Professional Psychology, San Diego

Riege, A. M. (2003). Validity and reliability tests in case study research: A literature review with "handson" applications for each research phase. Qualitative Market Research: An International Journal, 6(2), 75-86. https://doi.org/10.1108/13522750310470055

Santilli, S., Nota, L., \& Hartung, P. J. (2019). Efficacy of a group career construction intervention with early adolescent youth. Journal of Vocational Behavior, 111, 49. https://doi.org/10.1016/j.jvb.2018.06.007

Savickas, M. L. (1997). Career adaptability: An integrative construct for life-span, life-space theory. The Career Development Quarterly, 45(3), 247-259. https://doi.org/10.1002/j.2161-0045.1997.tb00469.x

Savickas, M. L. (2002). Career construction: A developmental theory of vocational behaviour. In D. Brown \& L. Brooks (Eds.), Career Choice and Development (4th ed., pp. 149-205). Jossey-Bass.

Savickas, M. L. (2006). Career construction theory. In J. H. Greenhaus \& G. A. Callanan (Eds.), Encyclopedia of Career Development (Vol. 1, pp. 85-89). Sage.

Savickas, M. L. (2012a). The 2012 Leona Tyler award address: Constructing careers-actors, agents and authors. The Counseling Psychologist, 41(4), 648-662. https://doi.org/10.1177/0011000012468339

Savickas, M. L. (2012b). Life design: A paradigm for career intervention in the 21st century. Journal of Counselling \&amp; Development, 90(1), 13-20. https://doi.org/10.1111/j.1556-6676.2012.00002.x

Savickas, M. L. (2015). Life-Design Counseling Manual. Author.

Savickas, M. L. (2019). Theories of Psychotherapy Series Career Counselling (2nd ed.). New York: American Psychological Association.

Savickas, M. L. (2019b, September). Designing a self and constructing a career in post-traditional societies. Keynote address at the 43rd international association for educational and vocational guidance Conference, Bratislava, Slovakia

Savickas, M. L., Nota, L., Rossier, J., Dauwalder, J.-P., Duarte, M. E., Guichard, J., \& Van Vianen, A. E. (2009). Life ***designing: A paradigm for career construction in the 21 st century. Journal of Vocational Behavior, 75(3), 239-250. https://doi.org/10.1016/j.jvb.2009.04.004

Savickas, M. L., \& Porfeli, E. J. (2012). Career Adapt-Abilities scale: Construction, reliability, and measurement equivalence across 13 countries. Journal of Vocational Behavior, 80(3), 661-673. https://doi.org/ 10.1016/j.jvb.2012.01.011

Schreuder, D., \& Coetzee, M. (2013). Careers: An Organisational Perspective (4th ed.). Juta.

Schyns, B., \& Von Collani, G. (2002). A new occupational self-efficacy scale and its relation to personality constructs and organizational variables. European Journal of Work and Organizational Psychology, 11(2), 219-241. https://doi.org/10.1080/13594320244000148

Super, D. E. (1957). The Psychology of Careers: An Introduction to Vocational Development. Harper.

Wells, D. K. (2011). Women in the Middle (Unpublished master's thesis.) ProQuest LLC, Ann Arbor, Michigan

Young, R. A., \& Collin, A. (2004). Introduction: Constructivism and Social constructionism in the career field. Journal of Vocational Behaviour, 64(3), 373-388. https://doi.org/10.1016/j.jvb.2003.12.005

Publisher's Note Springer Nature remains neutral with regard to jurisdictional claims in published maps and institutional affiliations. 